Journal Of Agriculture and Social Research (JASR) Vol. 8, No.1, 2008

\title{
CORRELATES OF INORGANIC FERTILIZER CONSUMPTION AMONG SMALLHOLDER FARMERS IN ABIA STATE, NIGERIA
}

\author{
C.I. EZEH, O.W. ONWUKA AND I. N. NWACHUKWU
}

\begin{abstract}
This paper investigated the correlates of inorganic fertilizer consumption among smallholder farmers in Abia State, Nigeria A multi-stage random sampling technique was employed in selected local government areas, communities and respondents from the three agricultural zones (Aba, Ohafia and Umuahia) of the state. The sample size was 150. The results of the linear functional model indicate that four (farmer incomes, farm experiences, transportation costs and price of $50 \mathrm{~kg}$ fertilizer bag) out of the eight variables were key determinants of the smallholder farmers' fertilizer consumption at 5\% risk level. However the combined effects of all the variables explained 57.6 percent of the variations in the total fertilizer consumption rate of the smallholder farmers in Abia state Nigeria. Higher level of subsidy on fertilizer is recommended as a deliberate policy to increase the fertilizer consumption propensity of the smallholder farmers.
\end{abstract}

Key words: Correlates, Inorganic Fertilizer, Consumption, Smallholder farmer.

\section{INTRODUCTION}

The growing demand for food in both rural and urban areas requires that agricultural productivity must increase. Historical gains in agricultural production in Nigeria have been achieved through expansion of areas cultivated (Dangote, 2003). However, population growth and pressure in Nigeria have affected negatively the supply of productive land in the country (Nwagbo and Achoja, 2001). Farmers are now forced to reduce the length of fertility - restoring fallows and expand into environmentally fragile land. Increased cultivation on less productive lands is a major cause of declining yields among smallholder farmers. To reverse the declining yield trends, intensification through the use of inorganic fertilizers and other land augmenting technologies is very essential. Experiences have shown that chemical fertilizer is one of the most reliable productivity enhancing inputs available (Onwuka, 2005).

In Nigeria, the estimated demand for all fertilizer types in 1995 was 6.6 million metric tons but only 700, 000 metric tons were actually consumed (FFD, 2002). This low fertilizer use rate constitutes serious impediment to the growth and development of agriculture. Crop yields in some locations have been observed to be severely limited by suboptimal fertilizer consumption. Thus, inorganic fertilizer utilization of the smallholder farmers ought to improve over time and space. Just as there is strong correlation between crop yield and the volume of fertilizer utilization, so there ought to exist a relationship between the fertilizer consumption of the farmer and selected socio economic indicators (Nwagbo and Achoja, 2001). But it is difficult to generalize about the economic variables that are responsible for the growth in fertilizer demand. For instance, variables which may correlate with fertilizer consumption may relate to price of farm produce, market access conditions, fertilizer price per bag, farm size, farm income to mention but a few and each could have its own set of assumption (Abott, 1993; Akinola and Young, 1991; Nwagbo and Achoja, 2001).

It is important to determine the socio - economic roles in shaping fertilizer consumption pattern. This is necessary because estimating periodic changes in fertilizer consumption may not provide sufficient insights. Thus, constructing fertilizer consumption models around some associated socio - 
economic correlates becomes an important exercise that is critical to effective and sustainable inorganic fertilizer consumption (Nwagbo and Achoja, 2001). Therefore, the specific objectives of this paper:

i. to describe socio - economic variables of the smallholder farmers in the State;

ii. to determine the socio - economic factors that affect the demand for inorganic fertilizer

iii. make policy recommendations based on the research findings.

\section{Hypothesis}

$\mathbf{H}_{\mathbf{a}}$ : Quantity of fertilizer consumed is positively related to amount of credit, farm income, farm size, farming experience, extension contact and negatively related to transportation cost and fertilizer price.

\section{METHODOLOGY}

The research was conducted in Abia State, Nigeria. Multistage random sampling technique was used in the selection of Local Government Areas, autonomous communities and farmers. Two local government areas were randomly selected from each agricultural zone of the state. The local government areas selected were Obingwa and Ukwa - east (Aba zone), Umuahia North and Ikwuano (Umuahia zone) and Umunneochi and Isikwuato (Ohafia zone). In stage two, five autonomous communities were selected at random from each of the six local government areas. Finally, 5 smallholder inorganic user farmers each were selected at random from the 30 autonomous communities. This gave a sample size of one hundred and fifty (150) smallholder farmers. The sample frames were obtained from the agro - service centres in each agricultural zone. Instrument of data collection was a set of questionnaire administered to the farmers.

For the purposes of this study, descriptive and inferential statistics were used. Descriptive statistics used include tables, percentages and means. The economic analyses adopted in this paper followed that of Ezeh $(2003 ; 2006)$ in some functional forms of multi regression were analyzed. Its specified as follows:

$\mathrm{Y}=\mathrm{f}\left(\mathrm{X}_{1}, \mathrm{X}_{2}, \mathrm{X}_{3}, \mathrm{X}_{4}, \mathrm{X}_{5}, \mathrm{X}_{6}, \mathrm{X}_{7}, € \mathrm{i}\right)$

Where:

$\mathrm{Y}=$ Quantity of inorganic fertilizer consumed $(\mathrm{kg})$

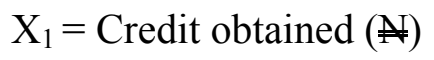

$\mathrm{X}_{2}=$ Farm income $(\#)$

$\mathrm{X}_{3}=$ Farm size (ha)

$\mathrm{X}_{4}=$ Farming experience (Years)

$\mathrm{X}_{5}=$ Transportation cost to fertilizer store (

$\mathrm{X}_{6}=$ Price of fertilizer per $50 \mathrm{~kg}$ bag $(\#)$

$\mathrm{X}_{7}=$ Frequency of Extension Agent contact

$€ \mathrm{i}=$ Stochastic term 
For this study, three functional forms of the regression model were estimated, linear, double log and semi - log. The linear regression model was chosen as the lead predictive equation based on the number of significant variables that are correctly signed, higher values of $\mathrm{R}^{2}$ and $\mathrm{F}$ - ratio.

\section{RESULTS AND DISCUSSION}

Table 1 shows that $36.0 \%$ of the smallholder farmers were in the age range of $41-50$ years were closely $(25.35 \%)$ followed by respondents in the age range of $51-60$ years. This implies that the respondents in the study area were still within the active and productive farming group.

Table 1: Distribution of respondents According to socio-economic characteristics $(\mathbf{n}=150)$

$\begin{array}{clc}\text { Categories of Age (Years) } & \text { Frequency } & \text { Percentage } \\ 21-30 & 2 & 1.33 \\ 31-40 & 34 & 22.67 \\ 41-50 & 54 & 36.00 \\ 51-60 & 38 & 25.33 \\ \text { Above } 60 & 22 & 14.67\end{array}$

$\begin{array}{clc}\text { Household size } & \text { Frequency } & \text { Percentage } \\ 1-4 & 39 & 26.00 \\ 5-8 & 95 & 63.33 \\ 9-12 & 16 & 10.67\end{array}$

$\begin{array}{lll}\text { Level of Education } & \text { Frequency } & \text { Percentage } \\ \text { No formal Education } & 7 & 4.67 \\ \text { FSLC } & 72 & 48.00 \\ \text { WAEC/GCE/SSCE/NABTEB/TC II } & 44 & 29.33 \\ \text { OND/NCE } & 16 & 10.67 \\ \text { HND/B.Sc } & 11 & 7.33\end{array}$

$\begin{array}{lll}\text { Farm income (N) } & \text { Frequency } & \text { Percentage } \\ 1,000.00-11,000.00 & 38 & 25.33 \\ 11,001.00-21,000.00 & 45 & 30.00 \\ 21,001.00-31,000.00 & 30 & 20.00 \\ 31,001.00-41,000.00 & 13 & 8.67 \\ 41,001.00-51,000.00 & 11 & 7.33\end{array}$



Above
$51,001.00$
13
8.67

Farm size

$0.1-2.0$

$2.01-3.0$

$3.01-4.0$

$4.01-5.0$

Above 5.01

\section{Frequency}

124

17

5

2

2

Frequency

81

46

18

4

1

Frequency

66

39

33

9

3

Above 400.00

\section{Extension visits}

Weekly

Fortnightly

Monthly

No fixed visit schedule

$\begin{array}{rcc} & \text { Frequency } & \text { Percentage } \\ 17 & 11.33 \\ 115 & 76.67 \\ 5 & 3.33 \\ 13 & 8.67\end{array}$

Table 1 also shows that majority $(63.33 \%)$ of the respondents had a household size of $5-8$ persons. The desire for large families in the rural areas is expected obvious. Large household sizes supply the much-needed labour for farm work as well as serve as a cushion against social insecurity in terms of old age (Ezeh, 2006). The results show that majority $(95.33 \%)$ of the respondents had one form of literacy level or the other. The increased level of literacy level among the respondents could be attributed to the seemingly positive effects of the free (Universal Basic education Scheme). Higher 
literacy level of the respondents has a serious but significant implication in the adoption of improved practices. The more educated a farmer is, the more likely he is to adopt new ideas (Onuoha, 2006).

About $30.0 \%$ of the respondents were within the income range of $\$ 11,001-21,000.00$ while $8.67 \%$ of them had the highest farm income above 51,000. 00. This indicates that smallholder farmers in the state operated at merely subsistent level. This low income status has serious deleterious implications on their farm investments and agricultural productivity (Ezeh, 2006).

The distribution of the respondents according to farm size shows that majority $(82.67 \%)$ of the respondents had farm sizes ranging from $0.1-2.0$ hectares. This is a confirmation that smallholder farmers are operating on a smallholding. Farm sizes are affected by the terminal system of land acquisition (Okorji, 1999). This implies that resources will be under - utilized and maximum output will not be achieved in most cases.

Majority (54.0\%) of the respondents had less than 10 years of farming experience. Farmers with larger years of farming experience are better positioned to make rational choice and decide among alternative farm inputs (Onwuka, 2001). The result also shows that the modal response $(44.0 \%)$ indicates that transportation cost per bag of fertilizer was in the range of $\$ 50.00-100.00$. High transportation cost engendered by long distance reduces the quantity of fertilizer a smallholder farmer would purchase and consume and this has serious implication in productivity. Majority (76.67\%) of the respondents indicated that the Extension Agents of the Abia State Agricultural Development Programme adopted fortnightly visits. Regular visits by the Extension Agents are of significance to the application of modern farm inputs by smallholder farmers. The visits translate into increased chances of the farmers in learning new technologies from the agents.

\section{Factors Determining Fertilizer Consumption in Abia State Nigeria}

The results of the multiple regression analysis are shown in table 2 . The lead equation is the linear functional form. This is based on econometric and statistical reasons. The cross sectional analysis of the factors that influence fertilizer consumption by smallholder farmers in Abia state, indicate that the results have provided reasonably good estimate of the underlying socio - economic characteristics that affect the total quantities of fertilizer consumed by the smallholder farmer in Abia state $\left(\mathrm{R}^{2} .=0.567\right)$. Examining briefly, the individual characteristics of the aggregate fertilizer demand equation, results show that four out of the eight explanatory variables had significant coefficients in the equation. They include farm income $\left(\mathrm{X}_{2}\right)$, Farming experience $\left(\mathrm{X}_{4}\right)$, Transportation cost $\left(\mathrm{X}_{5}\right)$ and price of fertilizer $\left(\mathrm{X}_{6}\right)$.

Table 2: Estimates of factors Determining Fertilizer Consumption in Abia State Nigeria

\begin{tabular}{|c|c|c|c|c|}
\hline $\begin{array}{c}\text { Independent } \\
\text { Variables } \\
\end{array}$ & & Linear & Semi - log & Double - log \\
\hline Constant & & $\begin{array}{l}92.714 * * \\
(43.529)\end{array}$ & $\begin{array}{c}-927.429 \\
(1203.697)\end{array}$ & $\begin{array}{l}-8.148 \\
(7.544)\end{array}$ \\
\hline Credit Obtained & $=\mathrm{X}_{1}$ & $\begin{array}{c}-1.361 \mathrm{E}-03 \\
(0.002)\end{array}$ & $\begin{array}{c}22.330 \\
(36.022)\end{array}$ & $\begin{array}{l}9.100 E-02 \\
(0.226)\end{array}$ \\
\hline
\end{tabular}


Journal Of Agriculture and Social Research (JASR) Vol. 8, No.1, 2008

\begin{tabular}{|c|c|c|c|c|}
\hline Farm Income & $=X_{2}$ & \multicolumn{2}{|c|}{$\begin{array}{ll}2.196 \mathrm{E}-03 * * & -21.989 \\
(0.001) & (60.794)\end{array}$} & $\begin{array}{c}0.347 \\
(0.381)\end{array}$ \\
\hline Farm size & $=\mathrm{X}_{3}$ & $\begin{array}{c}42.234 \\
(25.719)\end{array}$ & $\begin{array}{l}63.799 \\
48.727)\end{array}$ & $\begin{array}{c}0.202 \\
(0.305)\end{array}$ \\
\hline Farm experience & $=\mathrm{X}_{4}$ & $\begin{array}{l}1.582 * * \\
(0.693)\end{array}$ & $\begin{array}{r}-38.510 \\
(44.079)\end{array}$ & $\begin{array}{r}-0.159 \\
(0.276)\end{array}$ \\
\hline Transportation costs & $=\mathrm{X}_{5}$ & $\begin{array}{l}-8.231 E-02 * * \\
(0.029)\end{array}$ & $\begin{array}{l}-0.537 \\
(50.515)\end{array}$ & $\begin{array}{c}-3.137 E-02 \\
(0.317)\end{array}$ \\
\hline Fertilizer Price & $=\mathrm{X}_{6}$ & $\begin{array}{l}-3.650 \mathrm{E}-03 * * \\
(0.001)\end{array}$ & $\begin{aligned} & -25.573 \\
& (58.403)\end{aligned}$ & $\begin{array}{r}-0.150 \\
(0.366)\end{array}$ \\
\hline \multicolumn{2}{|c|}{ Frequency of Ext. Contact $=\mathrm{X}_{7}$} & $\begin{array}{c}1.145 \\
(1.647)\end{array}$ & $\begin{array}{c}442.942 \\
(272.236)\end{array}$ & $\begin{array}{l}3.247 \\
(1.706)\end{array}$ \\
\hline $\mathrm{R}^{2}$ & & 0.567 & 0.234 & 0.409 \\
\hline $\mathrm{F}-$ ratio & & $2.916^{* *}$ & 0.612 & 1.382 \\
\hline
\end{tabular}

Source: Computed from Field Survey Data, 2006

*** Variable significant at 1.0 percent; **Variable significant at 5.0 percent

* Variable significant at 10.0 percent

Figures in parentheses are the standard errors

$\mathrm{n}=150$

The coefficient of farm income $(2.196 \mathrm{E}-03)$ is positive and the standard error is 0.002 and the variable is statistically significant at 5.0 percent level of probability. The sign of the coefficient is in conformity with a prior expectation that quantity of fertilizer consumption would increase as the resource holdings (income) of the farmer increases and vice versa. Farmers would be more disposed to purchase and use more fertilizer when their income increases (Abott, 1993; Mbanasor, 1997; Nwagbo and Achoja, 2001). Hence, the smallholder farmers in the study area are indeed displaying rational economic behaviour.

Farmers' previous experience in fertilizer consumption coefficient (1.582) is positive with a standard error of 0.693 and statistically significant at 5.0\% level. The implication is that fertilizer consumption of the farmer was sensitive to the farmers' previous experience in fertilizer use (Nwagbo and Achoja, 2001). This variable gives an indication of both the length of farming experience and accumulation of capital. An experienced farmer is more likely to have realized the importance of inorganic fertilizer and even where credit facilities are not available, such a farmer is more likely to have advantage of fertilizer consumption (Oji, 1997; Nwagbo and Achoja, 2001). Thus previous experience would sustain farmers' interest in the use of fertilizer.

Transportation cost to the nearest fertilizer selling centers was selected as a proxy for market access condition in the study area. As predicted, the coefficient $(-8.231 \mathrm{E}-02)$ is negative while the standard error is 0.029 . This variable is statistically significant at $5.0 \%$ probability level. The 
negative sign associated with the variable implies that a high transportation cost of which is a reflection of poor market access) would reduce the quantity of fertilizer a smallholder farmer would purchase and consume (Nwagbo and Achoja, 2001). Oji (1997) had noted that a better market access condition would give room for scope of fertilizer market coverage. Therefore better rural road network would encourage sustainable fertilizer consumption by rural farmers.

The price of fertilizer variable posted a negative $(-3.650 \mathrm{E}-03)$ contribution to the fertilizer consumption equation is statistically significant at 5.05 level. The coefficient of this variable is negative is in conformity with a prior expectation that the quantity of fertilizer per bag increases. This is in consonance with Aluko (1987) that an increase in fertilizer price would lead to its under consumption by the resource - poor farmers.

\section{CONCLUSION AND POLICY RECOMMENDATIONS}

Apart from having a good knowledge of the soil nutrient potential, there are other factors, which may affect the demand for fertilizers. Sustainable fertilizer consumption equation among smallholder farmers must incorporate farm income, farm experience transportation cost and price per bag of fertilizer. The results further imply that fertilizer consumption would be optimized if policies are focused on complementary economic correlates subsistence farmers. The following policy recommendations are made:

i. The smallholder farmers should form cooperatives to enable them shore up and pool resources together in order to enjoy economies of scale in terms of fertilizer procurement and transportation.

ii. A higher level of subsidy is advocated for fertilizer. It is by reducing the cost of fertilizer through subsidies that aids in accelerating the "learning process" and promoting its use. This "subsidy - push strategy" for inducing fertilizer use is generally recommended for the smallholder farmers who are still at the introductory stage of development. Once, the fertilizer use reaches the "take - off" stage, there is little need for the input subsidy.

iii. More agro - service centers should be established at political ward level. This has the direct effect of reducing the transportation cost and distances in the procurement of this input.

iv. Rural infrastructure such as roads, electricity and telecommunication should be established and/or properly maintained where available in the rural areas by the governments at all levels. This is due to the positive multiplier effects of these facilities both in the producers and consumers of fertilizers.

\section{REFERENCES}

Abott, J.C. (1993) "Financing Fertilizer Distribution Network" In Abott, J.C. (ed) Agricultural and Food marketing in Developing Countries, Selected Reading, U.K. CTA International Publication.

Akinola, A.A and T. Young (1991) "Application of the Tobit Model in the Analysis of Agricultural Innovations Adopted Process: A Study of the Use of Cocoa Spraying Chemical Among Cocoa Farmers: In Agricultural Systems, 36: 36 - 26- 51. 
Aluko, O.I. (1981) "An Appraisal of the $2^{\text {nd }}$ - tier Foreign Exchange Market (SFEM)" In: Phillip and Adekun (eds) Structural Adjustment Programme in Developing Economy: The Case of Nigeria. NISER, Ibadan

Dangote, S. (2003) “An Overview of Fertilizer Importation and Distribution in Nigeria". A paper presented at National Agri - Input Policies Workshop organized by IFDC Nigeria. NICON Hilton Hotel Abuja. $26^{\text {th }}-27^{\text {th }}$ August

Ezeh, C.I. (2003) "Agricultural Financing in Depressed Economy - The Socio - economic Determinants. Journal of Sustainable Tropical Agricultural Research 8:89-93.

Ezeh, C.I. (2006) "Socio - economic Determinants of Output and Profit Levels of Smallholder Rice Production Systems in Abia State, Nigeria". Journal of Research in Agriculture. 3(3) 44 50

FFD (Federal Fertilizer Department) (2002) Fertilizer Use and Management Practices For Crops in Nigeria. FFD Abuja.

Mbanasor, J.A. (1999) "An Econometric Study of the Production Efficiency of Rural Farmers in South - Eastern Nigeria under SAP" Ph.D Thesis. Department of Agricultural Economics. University of Nigeria.

Nwagbo, E.C. and Achoja, F.O. (2001) "Correlates of Sustainable Fertilizer Consumption Among Smallholder Farmers: An Econometric Approach". A paper presented at the Annual conference of Nigeria Association of Agricultural Economists at the University of Nigeria Nsukka $11-13^{\text {th }}$ June.

Oji, K.O. (1999) "Trends in Agricultural Intensification Under population Pressure among Smallholder Farmers in Imo and Abia States of South - eastern Nigeria" Ph.D Thesis. Department of Agricultural Economics. U.N.N.

Okorji, E.C. (1999) “ Dimensions of Rural Poverty and Food Self - Sufficiency in Nigeria: In Y.C. Fabiyi and E.O. Idowu (eds) Poverty Alleviation and Food Security. NAAE Ibadan.

Onuoha, C. (2006) “Financial Analysis of Small - Scale Okra Production in Ebonyi State, Nigeria”. M.Sc Dissertation. Department of Agriculture, Abia State University Uturu.

Onwuka, O.W. (2005) "Socio - economic Determinants of Inorganic Fertilizer Consumption Among Smallholder Farmers in Abia State, Nigeria". M.Sc Dissertation. Dept. of Agriculture, Abia State University Uturu 